\title{
Antidiabetic, antioxidant and in silico studies of bacterial endosymbiont inhabiting Nephelium lappaceum $\mathbf{L}$.
}

\author{
Sridevi CHIGURUPATI ${ }^{*}{ }^{1}$ Shantini VIJAYABALAN,${ }^{2}$ Arunkumar KARUNANIDHI, ${ }^{3}$ \\ Kesavanarayanan KRISHNAN SELVARAJAN, ${ }^{4}$ Sitansu Sekhar NANDA ${ }^{\dagger},{ }^{5}$ and \\ Raghunath SATPATHY ${ }^{6}$ \\ ${ }^{I}$ Department of Medicinal Chemistry and Pharmacognosy, College of Pharmacy, Qassim University, Buraidah \\ 52571, Kingdom of Saudi Arabia \\ ${ }^{2}$ Department of Pharmaceutical Chemistry, Faculty of Pharmacy, AIMST University, Kedah, Malaysia \\ ${ }^{3}$ Department of Pharmacology and Chemistry, Faculty of Pharmacy, Universiti Teknologi MARA, 42300 Bandar \\ Puncak Alam, Selangor Darul Ehsan, Malaysia \\ ${ }^{4}$ Department of Pharmacology \& Toxicology, College of Pharmacy, University of Hail, Hail, Kingdom of Saudi \\ Arabia \\ ${ }^{5}$ Department of Chemistry, Myongji University, Yongin, South Korea \\ ${ }^{6}$ Department of Biotechnology, MITS Engineering College, Rayagada, Odisha-765017, India
}

\begin{abstract}
Endophytes, notably obtaining attention, have been abided by potential origins of bioactive metabolites. In the acquaint study, endophyte was isolated from the leaves of Nephelium lappaceum L. The chosen endosymbiont was identified by $16 \mathrm{~s}$ rRNA partial genome sequencing and investigated for their antioxidant and antidiabetic activities. A preliminary phytochemical test was comported for the affirmation of phytoconstituents in endophytic crude extract (NLM). Antioxidant activities were conducted by using 2-diphenyl-1-picrylhydrazyl (DPPH) method and 2,2'-azino-bis3-ethylbenzthiazoline-6-sulphonic acid (ABTS) method to screen the radical scavenging potential. The evaluation of antidiabetic activities was done by using $\alpha$-amylase and $\alpha$-glucosidase inhibition assay. Qualitative phytochemical test on NLM affirmed the presence of phenols, carbohydrates, alkaloids, flavonoids, steroids, mucilage and glycosides. In silico parameters were also specified for antidiabetic activities. The antioxidant assay of NLM expressed proficient antioxidant activity of $\mathrm{IC}_{50} \pm \mathrm{SEM} 1.35 \pm 0.03 \mu \mathrm{g} / \mathrm{mL}$ and $\mathrm{IC}_{50} \pm \mathrm{SEM} 1.47 \pm 0.03 \mu \mathrm{g} / \mathrm{mL}$, for ABTS and DPPH respectively. Antidiabetic assay results evidenced dose dependent percentage inhibition of the enzyme. The results testified estimable inhibition of $\alpha$-amylase ( $\mathrm{IC}_{50} \pm$ SEM $2.549 \pm 0.08 \mu \mathrm{g} / \mathrm{mL}$ ) and $\alpha$-glucosidase inhibition ( $\mathrm{IC}_{50} \pm \mathrm{SEM} 2.29 \pm 0.03 \mu \mathrm{g} / \mathrm{mL}$ ) compared to the standard drug (Acarbose). In silico study divulged that the ellagic acid component present in the plant was responsible for antidiabetic activity. Thus, the study shows that NLM has a wellspring of natural source of antioxidants and antidiabetic agents and furtherance of studies on its mechanism is recommended to know detailed facts.
\end{abstract}

Keywords: Nephelium lappaceum, antioxidant, $\alpha$-amylase, $\alpha$-glucosidase, endophyte, Escherichia coli.

\section{Introduction}

Endophytes are notable mutualistic symbiont inhabitants within the living tissues of host plants without causing any effects. Endophytes can be distinguished as bacteria, actinomycetes or fungi. Because of the long host-parasitic relationship, endophytes can are able to produce secondary metabolites similar to that of plants. They are a wellspring of secondary metabolites, which exhibited many pharmacological activities, for instance: anticancer, antidiabetic, antifungal and antibacterial activities [1]. From a practical perspective, drug production by endophytes fermentation will provide more benefit since it will be quick, reproducible, boundless and climate/season independent. Simple to increase the microbial ability by genetic engineering and diverse cultivation condition which can produce various products. The disclosure of endophytes with a capacity to produce precisely the same active compounds produced by their host prompts another approach in active compound generation from natural product economically [1,2]. Production of compounds can be enhanced by endophytes for bearing demands while keeping the ecosystem and biodiversity sustainable. Endophytes have pulled from into consideration in the discovery of novel bioactive compounds that can be utilized as new medications supplanting those against which pathogenic strains have quickly obtained resistance [3].

Diabetes mellitus is a metabolic disorder which happens because of impeded glucose regulation or weakened of the $\alpha$-amylase enzyme. It relates to an increased risk of cardiovascular disease. Most diabetic cases included numerous genes with each being a small contributor to an increased likelihood of getting to be Type 2 diabetic and it additionally relies on the lifestyle. The medications conventionally use synthetic drugs all

\footnotetext{
* Corresponding author. E-mail address: sridevi.phd@gmail.com (Sridevi Chigurupati).

$\dagger$ Corresponding author. E-mail address: nandasitansusekhar@gmail.com (Sitansu Sekhar Nanda).
} 
through their lifetime. Notwithstanding, long haul treatment had adverse effects, for example, oedema with gastrointestinal disorders and hyponatremia [4]. The result is inclined of today's society to favor traditional medications due to fewer side effects, sensible vale and less complex to situate in the surroundings [5].

There are unsettling impacts in antioxidant defense frameworks in diabetes mellitus [6]. As diabetic intricacies can be treated with antioxidants [7]. The commencement of the "unifying theory" that hyperglycemia-prompted oxidative stress could relate to the pathogenesis of each complexities [8].

Rambutan (Nephelium lappaceum L.) belongs to the Sapindaceae family is a popular tropical fruit in Southeast Asian countries namely in Indonesia, Thailand, and Malaysia. This tropical fruit is cultivated in a warm, humid, and in areas with lower evaporation rates and more rainfall. Rambutan is a red or yellow pericarp ovoid fruit which is covered with soft spines [9]. There are many traditional uses of rambutan and parts of the plant in local cultures are studied. Rambutan leaves are employed for hair care in the sense of increasing one's quality of hair [10]. Studies have reported that all parts of rambutan are useful where the leaves, rind, and seed contain anthocyanins, phenolic and flavonoids [11]. These parts are also reported to exhibit antioxidant, antibacterial, antidiabetic and cytotoxic activities [9]. The hydroxyl moiety of rambutan's phenolic compound has radical scavenging properties and reduces lipid peroxidation cell capacity. In the present study, we mainly focused on the isolated endophytes from rambutan leaves along with the screening of antioxidant and antidiabetic potentials of secondary metabolites of crude extracts of endophytes.

\section{Experimental}

\subsection{Chemicals}

2-diphenyl-1-picrylhydrazyl (DPPH), $\alpha$-amylase, $\alpha$ glucosidase, ascorbic acid, and gallic acid were purchased from Merck Millipore Corporation, USA. 2,2'-azino-bis-3-ethylbenzthiazoline-6-sulphonic acid (ABTS), Acarbose and Rutin were purchased from Sigma-Aldrich Corporation, USA. All the chemicals used were of analytical grade.

\subsection{Plant sample collection}

The plant materials, leaves of Nephelium lappaceum L. were collected from Baling, 09100, Kedah, Malaysia. The leaves were sampled for the study of endophytic bacterial communities. The matured and healthy plant was carefully selected for sampling, then were brought in sterile bags and processed within a few hours. The herbarium accession number of Nephelium lappaceum L. is AIMST/FOP/04.

\subsection{Isolation of endophytic bacteria}

The plant materials were rinsed gently in running water to remove superficial injury and soil particles. After proper washing, the samples were cut into small pieces. The isolation of endophytes was done according to the method described by Sadrati et al. (2013) with slight modifications [12, 13]. The surface sterilization was carried out by treating the plant material with $70 \%$ ethanol for 30 seconds, followed by immersion in $95 \%$ ethanol for 10 seconds and again in 5\% sodium hypochlorite solution for $4 \mathrm{~min}$. Subsequently, the segments were rinsed four times with sterile distilled water. The samples were cut into at least 3 to $4 \mathrm{~mm}$ in diameter and 0.5 to $1 \mathrm{~cm}$ in length. On each Petri plate, 5 to 6 segments were placed on the nutrient agar. The efficiency of the surface sterilization procedure was assessed by adding few drops of water from the last wash on the agar plate. The Petri plates were incubated at $37{ }^{\circ} \mathrm{C}$ for $24 \mathrm{~h}$ to $36 \mathrm{~h}$ until the growth of bacteria is observed.

\subsection{S rRNA partial gene sequencing}

The PCR amplification of 16S rRNA partial gene of the selected endophyte strains was done by using the forward primer (Bakll W-F 5'- AGT TTG ATC MTG GCT CAG -3') and reverse primer (Bak-R 5'- GGA CTA CHA GGG GGG TAT CTA AT -3'). The PCR amplification was carried out in a thermocycler with the following conditions: initial denaturation at $95^{\circ} \mathrm{C}$ for 4 min, cycle denaturation at $9^{\circ} \mathrm{C}$ for $30 \mathrm{~s}$, cycle annealing at $52{ }^{\circ} \mathrm{C}$ for $30 \mathrm{~s}$, cycle extension at $72{ }^{\circ} \mathrm{C}$ for $30 \mathrm{~s}$, repeat cycle steps 30 more times, final extension $72{ }^{\circ} \mathrm{C}$ for 5 min. The sequenced DNA data were a BLAST analyzed by the NCBI database to identify the sequence similarity reported gene sequences in GenBank [14].

\subsection{Bacterial endophytic crude extraction}

The isolated endophyte was grown as the subculture on a nutrient agar Petri plate for $24 \mathrm{~h}$ under aerobic condition. The subculture was inoculated into the nutrient broth and incubated at $110 \mathrm{rpm}$ on a shaker at $37{ }^{\circ} \mathrm{C}$ for 3 to 4 days. After fermentation, the culture broth was added with brine solution and ethyl acetate solvent respectively, with the ratio of 1:3. The culture broth was then extracted. The organic phase was filtered after which anhydrous sodium sulphate was added. The ethyl acetate solvent was evaporated by rotary evaporator. The extract was dried and concentrated, then was weighed and stored at $-4{ }^{\circ} \mathrm{C}[15]$.

\subsection{Phytochemical screening}

NLM was used for preliminary screening of phytochemicals such as alkaloids, carbohydrates, phenols, amino acids, steroids, anthocyanins, proteins, flavonoids, saponins, mucilage, gums, glycosides and tannins using standard biochemical testing methods [16].

\subsection{Antioxidant activity}

\section{DPPH free radical scavenging assay}

The sample DPPH free radical scavenging capacity was assessed by using standard method [17, 18]. The sample solutions were prepared in absolute alcohol, ranging from $10 \mu \mathrm{g} / \mathrm{mL}$ to $1000 \mu \mathrm{g} / \mathrm{mL}$. The sample $(500 \mu \mathrm{L})$ was added with $2 \mu \mathrm{mol}$ DPPH solution $(500 \mu \mathrm{L})$ and kept in the dark for $20 \mathrm{~min}$ at room temperature. The absorbance was measured at $517 \mathrm{~nm}$. Ascorbic acid was used as a reference standard.

The percentage of free radical scavenging was calculated as:

$$
\% \text { Inhibition }=\frac{A b s_{\text {control }}-A b s_{\text {sample }}}{A b s_{\text {control }}} \times 100
$$


where $A b s$ is absorbance.

\section{ABTS free radical cation scavenging assay}

The sample capacity to scavenge, 2,2'-azino-bis (3ethylbenzothiazoline-6-sulfonic acid) free radical cation [ABTS*+] was assessed by standard method $[19,20] .7$ $\mathrm{mM}$ ABTS in distilled water and $2.45 \mathrm{mM}$ of potassium persulfate was added. The solution was kept at room temperature in the dark for 12 to $16 \mathrm{~h}$. The sample solutions were prepared in absolute alcohol, ranging from $10 \mu \mathrm{g} / \mathrm{mL}$ to $1000 \mu \mathrm{g} / \mathrm{mL}$. The ABTS solution was added and incubated for $30 \mathrm{~min}$. The absorbance was measured at $734 \mathrm{~nm}$. Ascorbic acid was used as reference standard. The percentage of radical cation scavenging inhibition was calculated using Eq. 1.

\subsection{In vitro antidiabetic activity $\alpha$-amylase inhibition assay}

The $\alpha$-amylase inhibitory activity was assayed by modifying assay [21]. The sample $(500 \mu \mathrm{L})$ was added with $0.5 \mathrm{mg} / \mathrm{mL} \alpha$-amylase solution $(500 \mu \mathrm{L})$ in $0.2 \mathrm{mM}$ phosphate buffer, $\mathrm{pH} 6.9$, and was incubated at $25^{\circ} \mathrm{C}$ for $10 \mathrm{~min}$. After the pre-incubation period, $1 \%$ starch solution $(500 \mu \mathrm{L})$ in $0.02 \mathrm{M}$ sodium phosphate buffer, $\mathrm{pH} 6.9$, was added and incubated for $10 \mathrm{~min}$ at $25^{\circ} \mathrm{C}$. After the addition of $1 \mathrm{~mL}$ of dinitrosalicylic acid color reagent, the solutions were kept for incubation in boiling water for $5 \mathrm{~min}$ subsequently cooled to room temperature. The absorbance was measured at $540 \mathrm{~nm}$. Acarbose was used as a reference standard. The percentage of inhibition was calculated using Eq. 1 .

\section{$\alpha$-glucosidase inhibition assay}

The $\alpha$-glucosidase inhibitory activity was assayed by modifying assay [22]. The sample $(1 \mathrm{~mL})$ and $2 \% \mathrm{M} / \mathrm{V}$ sucrose $(1 \mathrm{~mL})$ in Tris buffer, $\mathrm{pH} 8$, were incubated for $5 \mathrm{~min}$ at $37^{\circ} \mathrm{C}$. Then, $1 \mathrm{U} / \mathrm{mL} \alpha$-glucosidase $(1 \mathrm{~mL})$ was added and incubated at $37{ }^{\circ} \mathrm{C}$ for $10 \mathrm{~min}$. The reaction was arrested by heating in boiling water for $2 \mathrm{~min}$. The glucose content was measured by the glucose peroxidase method. Acarbose was used as a reference standard. The percentage of inhibition was calculated using Eq. 1.

\subsection{Statistical analysis}

The data were computed as mean \pm standard error mean (SEM) and conveyed in triplicates $(n=3)$ throughout the experimental procedures. The $\mathrm{IC}_{50}$ values for both antioxidant and antidiabetic studies are calculated using the Graph Pad Prism Software (Version 5) by non- linear regression graph plotted between the percentage of enzyme inhibition ( $x$ axis) against concentrations ( $y$ axis) for antidiabetic assay and between percentage of radical scavenging ( $x$ axis) against concentration ( $y$ axis) for antioxidant assay.

\subsection{In silico studies}

One of the important secondary metabolites commonly found in this plant is ellagic acid. The ellagic acid is dilactone of hexahydroxydiphenic acid (Figure 1). Due to different medicinal properties of ellagic acid, they have enabled the researcher to obtain its potential health benefits [23]. To illustrate the antidiabetic nature of the Rambutan plant product an in silico case study was performed. The binding affinity of the ellagic acid with two receptors, $\alpha$-amylase and $\alpha$-glucosidase was evaluated by molecular docking study by using HEX 8.0 tool [24].<smiles>O=c1oc2c(O)c(O)cc3c(=O)oc4c(O)c(O)cc1c4c23</smiles>

Figure 1. Structure of dilactone of hexahydroxydiphenic acid.

\section{Results and discussion}

Endophytic bacteria habitats in various plant tissues are relatively unstudied and are known to have a wellspring of novel natural products to be utilized as part of industry, agriculture and medicine. The significance of endophytes has become apparent recently when it was demonstrated that it plays a part as protecting the host plant against ailments and insects [25]. In this study, endophytes were isolated from the leaves of Nephelium lappaceum L. The surface sterilization of the excised tissue was carried out to ensure the expulsion of surface microbial flora especially epiphytes. The immersion of the tissue in sodium hypochlorite and ethanol demonstrated significant accomplishment in various studies to isolate the endophytes [26]. The small pieces of the plant tissue (leaves) under aseptic conditions were moved to the isolation media. The endophytes were chosen, and the cultures were selected by a repeated sub culturing on Lysogeny broth (LB) agar and characterized by16S rRNA gene sequencing.

The genome sequence data obtained from 16S rRNA gene, partial sequencing was used in the identification of bacterial endophyte. The $16 \mathrm{~S}$ rRNA sequence nucleotide blast analysis reveals the identities of the sample based on his analysis from Megablast (highly similar sequences) output. Based on the $16 \mathrm{~S}$ rRNA sequence nucleotide blast analysis, the closest hit was treated as the identity of the respective endophytes sample. Based on the results obtain through 16S rRNA sequence nucleotide blast analysis, the endophyte identified as Escherichia coli. The 16S rRNA gene fragment nucleotide sequences have been submitted to the GenBank/DDBJ/EMBL under accession number of MF615205.

On performing preliminary qualitative phytochemical analysis using standard procedures [27], NLM reported to have various phytoconstituents such as alkaloids, flavonoids, steroids, mucilage, proteins, reducing sugar and phenols.

Table 1. $\alpha$-amylase and $\alpha$-glucosidase enzyme inhibition by NLM and Acarbose

\begin{tabular}{|c|c|c|c|c|}
\hline \multirow{2}{*}{$\begin{array}{c}\text { Concen- } \\
\text { tration } \\
(\boldsymbol{\mu g} / \mathbf{m L})\end{array}$} & \multicolumn{2}{|c|}{$\boldsymbol{\alpha}$ - amylase } & \multicolumn{2}{c|}{$\boldsymbol{\alpha}$ - glucosidase } \\
\cline { 2 - 5 } & Acarbose & NLM & Acarbose & NLM \\
\hline 100 & 39.39 & 20 & 40 & 34.96 \\
\hline 200 & 57.58 & 41.21 & 52 & 48.72 \\
\hline 400 & 54.55 & 50.30 & 68.8 & 65.44 \\
\hline 800 & 69.70 & 58.48 & 80.8 & 78.08 \\
\hline 1000 & 93.94 & 84.55 & 90.4 & 88.48 \\
\hline $\mathrm{IC}_{50} \pm \mathrm{SEM}$ & $2.25 \pm 0.15$ & $2.549 \pm 0.08$ & $2.22 \pm 0.04$ & $2.29 \pm 0.03$ \\
\hline
\end{tabular}


The crude extract of endophyte is subjected to in vitro antioxidant assay and the scavenging effect of free radicals was screened by using both ABTS and DPPH methods. Ascorbic acid was used as a standard drug for both assays. The sample and standard are diluted in absolute alcohol at the concentrations of 10, 25, 50, 100, 250, 500 and $1000 \mu \mathrm{g} / \mathrm{mL}$. As depicted in Figure 2(a) and $2(\mathrm{~b})$, the scavenging effect of highest concentration, $1000 \mu \mathrm{g} / \mathrm{mL}$ of NLM and ascorbic acid showed $92.1 \%$ $\left(\mathrm{IC}_{50} \pm \mathrm{SEM} 1.35 \pm 0.03 \mu \mathrm{g} / \mathrm{mL}\right)$ and $96.7 \%\left(\mathrm{IC}_{50} \pm \mathrm{SEM}\right.$ $1.07 \pm 0.09 \mu \mathrm{g} / \mathrm{mL}$ ) respectively in ABTS assay. In DPPH assay, the scavenging effect of highest concentration, $1000 \mu \mathrm{g} / \mathrm{mL}$ of NLM and standard showed $89.5 \% \quad\left(\mathrm{IC}_{50} \pm\right.$ SEM $\left.1.47 \pm 0.03 \mu \mathrm{g} / \mathrm{mL}\right)$ and $94.38 \%\left(\mathrm{IC}_{50} \pm \mathrm{SEM} 1.37 \pm 0.09 \mu \mathrm{g} / \mathrm{mL}\right)$ respectively.

Plants have different free radicals scavenging molecules that are abundant in antioxidant activity [28]. Most plants are wellspring of phenolics, flavanols, carotenoids, vitamin $\mathrm{E}$ and ascorbic acid, which have the scavenging capability in the human system [29, 30]. Various polyphenolic constituents acquired from plants are more practical antioxidants and as needs it may be add to defensive effects in vivo. As indicated by past investigations [31], phytoconstituents with potent antioxidants have been known to be great enzyme inhibitors, hyperglycemia regulators and other diabetic intricacies resulting from oxidative stress.
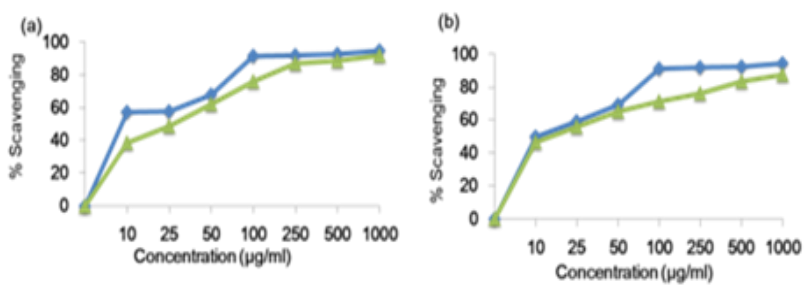

Figure 2 (a): ABTS radical scavenging assay of ascorbic acid (blue color) and NLM (green color); 2 (b): DPPH radical scavenging assay of ascorbic acid (blue color) and NLM (green color).

Compared with the standard Acarbose, the extract at maximum concentration showed significant $\alpha$ amylase inhibition activity of $84.55 \%\left(\mathrm{IC}_{50} \pm \mathrm{SEM} 2.549 \pm 0.08\right.$ $\mu \mathrm{g} / \mathrm{mL})$ and $93.94\left(\mathrm{IC}_{50} \pm \mathrm{SEM} 2.251 \pm 0.15 \mu \mathrm{g} / \mathrm{mL}\right)$ for NLM and Acarbose respectively as appeared in Table 1. For $\alpha$-glucosidase inhibition assay, the extract demonstrated that the concentration is dependent to percentage of $\alpha$-glucosidase inhibition. The concentration needed for $50 \%$ inhibition $\left(\mathrm{IC}_{50} \pm \mathrm{SEM}\right)$ was found to be $2.29 \pm 0.03 \mu \mathrm{g} / \mathrm{mL}$ for NLM. The $\mathrm{IC}_{50} \pm \mathrm{SEM}$ of Acarbose for $\alpha$-glucosidase inhibitory activity was found in $2.22 \pm 0.04 \mu \mathrm{g} / \mathrm{mL}$ as shown in Table 1 .

The pancreatic $\alpha$-amylase is one of the fundamental enzymes in the human stomach, as it breaks down starch into oligosaccharides and disaccharides. The glucose product is later ingested into the blood circulation. The $\alpha$-amylase inhibition would reduce the starch breakdown in the intestinal tract. In this way, the postprandial hyperglycemia level may decrease [32]. The enzyme inhibitory effect suggests that the active components (secondary metabolites) competes with the substrate for binding to the active site of the enzyme, thus preventing the breakdown of oligosaccharides to disaccharide and resulting from the anomalous bacterial fermentation of undigested carbohydrates in the colon and therefore mild enzyme activity is desirable [33].

Ellagic acid, which was found as important secondary metabolites of rambutan, and was chosen as a chemical constituent for the present in silico docking study [22]. One of the important secondary metabolites commonly found in this plant is ellagic acid. The docking conformation of the ellagic acid with the different receptors of $\alpha$-amylase and $\alpha$-glucosidase was depicted in Figure 3(a) and 3(b).

Several researches on ellagic acid have been done and specifically Chao et al. (2009) reported about the supplement of both ellagic acid can prevent diabetic cardiomyopathy [34]. Hex 8.0.0 is a popular protein docking program that contains an interactive molecular graphics program for calculating and displaying feasible docking modes of pairs of protein and ligand molecules. This program is capable of calculating the protein-ligand docking, assuming the ligand is rigid, also it superposes pairs of molecules using only knowledge of their 3D shapes. It uses Spherical Polar Fourier (SPF) correlations to accelerate the calculations and its one of the few docking programs which has built in graphics to view the results. During the docking process the default settings of the parameter were used in Hex 8.0 tools as shown in Table 2.

Table 2. Parameters set for the docking process.

\begin{tabular}{|c|c|c|}
\hline No. & Parameters & Set conditions \\
\hline 1 & Correlation type & Shape only \\
\hline 2 & FFT Mode & 3D fast lite \\
\hline 3 & Grid dimension & 0.6 \\
\hline 4 & Receptor range & 180 \\
\hline 5 & Ligand range & 180 \\
\hline 6 & Twist range & 360 \\
\hline 7 & Distance range & 40 \\
\hline
\end{tabular}

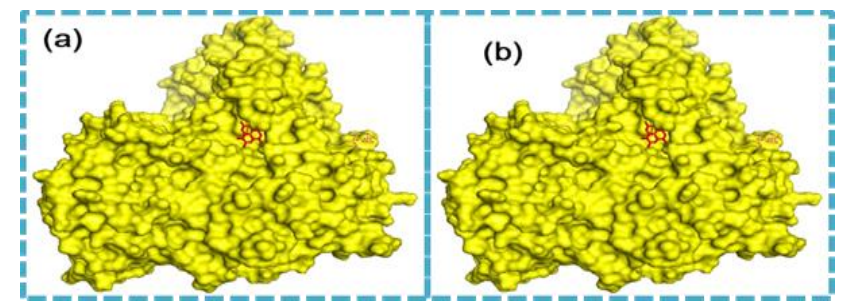

Figure 3(a): The docking conformation of the ellagic acid (red stick) with the different receptors (yellow in color) of $\alpha$ amylase; 3(b): The docking conformation of the ellagic acid (red stick) with the different receptors (yellow in color) of $\alpha$ glucosidase.

For docking study, the crystal structure was obtained from the protein data bank (PDB) available at www. rcsb.org/pdb. The PDB id 314w receptor was used for $\alpha-$ glucosidase and 3ole was used as the receptor for $\alpha$ amylase. Similarly, the ellagic acid structure was obtained from the pdb.

The docking energy ( $E$ values) was computed as 263.10 in case of $\alpha$-glucosidase and -278.79 for $\alpha$ amylase which is an indication of their interaction. The 
result showed the $E$ value obtained from the docking process is more compatible with the receptor that evaluates the antidiabetic nature of the ellagic acid. However, these molecules need to be further screened extensively through in vitro and in vivo experimentation before reaching any deceive conclusion.

\section{Conclusions}

The present study presumes that the presence of bioactive compound in the crude extract from the endophyte bacteria Escherichia coli, present in the leaves of Nephelium lappaceum L. exhibited promising antioxidant and antidiabetic properties. It merits saying that the Nephelium lappaceum L. which harbor the endophytes of the present study has been generally utilized in folklore medicine. Endophytes within these plants hold extraordinary potential in producing bioactive compounds. In silico study revealed that the ellagic acid component present in the secondary metabolite of the endophyte might be responsible for antidiabetic activity. Additional research like purification and fractionation of the active compounds in the crude extract of the endophyte and their structural elucidation will uncover the obscure compounds in the isolates and helps in the development of future drugs.

\section{Acknowledgements}

Authors are thankful to AIMST University, Malaysia and QASSIM University, Saudi Arabia for their support and facilities provided.

\section{Conflict of interest}

All the authors ensure that there is no conflict of interest regarding authorship, or any other matters pertaining to this manuscript.

\section{References}

[1]. K. Rajagopal, M. Sundharamoorthy, P. Arumugam, W. Jasmith Basha, K. Govindarajan, R. Rajendran, In vitro antibacterial activity of endophytic fungal extracts isolated from a pharmaceutically important plant Ficus religiosa L., Int. J. Pharma. Bio. Sci. 6 (2015) 1093-8.

[2]. J.K. Grover, S. Yadav, V. Vats, Medicinal plants of India with anti-diabetic potential, J. Ethnopharmacol. 81 (2002) 81-100.

[3]. S. Chigurupati, M.R. Marri, S. Vijayabalan, K.K. Selvarajan, Bacterial endo-symbiont Inhabiting Durio zibethinus leaves and their antibacterial potential, Int. J. Pharm. Tech. Res. 11 (2018) 198205.

[4]. A.J. Krentz, C.J. Bailey, Oral antidiabetic agents: Current role in type 2 diabetes mellitus, Drugs 65 (2005) 385-411.

[5]. R. Kasiviswanath, A. Ramesh, K.E. Kumar, Hypoglycemic and antihyperglycemic effect of Gmelina asiatica LINN. in normal and in alloxan induced diabetic rats, Biol. Pharm. Bull. 28 (2005) 729-32.
[6]. J. Strain, Disturbances of micronutrient and antioxidant status in diabetes, Proc. Nutr. Soc. 50 (1991) 591-604.

[7]. U. Salar, K.M. Khan, S. Chigurupati, S. Syed, S. Vijayabalan, A. Wadood, M. Riaz, M. Ghufran, S. Perveen, New hybrid scaffolds based on hydrazinyl thiazole substituted coumarin; As novel leads of dual potential; In vitro $\alpha$-amylase inhibitory and antioxidant (DPPH and ABTS radical scavenging) activities, Med. Chem. 15 (2019) 87-101.

[8]. M. Brownlee, Biochemistry and molecular cell biology of diabetic complications, Nature 414 (2001) 813-20.

[9]. A. Rohman, Physico-chemical properties and biological activities of rambutan (Nephelium lappaceum L.) fruit, Res. J. Phytochem. 11 (2017) 66-73.

[10]. M. Sekar, H. Merican, Formulation and evaluation of herbal shampoo containing rambutan leaves extract, Int. J. Pharma Bio Sci. 7 (2016) 146-151.

[11]. U. Palanisamy, H.M. Cheng, T. Masilamani, T. Subramaniam, L.T. Ling, A.K. Radhakrishnan, Rind of the rambutan, Nephelium lappaceum, a potential source of natural antioxidants, Food Chem. 109 (2008) 54-63.

[12]. N. Sadrati, H. Daoud, A. Zerroug, S. Dahamna, S. Bouharati, Screening of antimicrobial and antioxidant secondary metabolites from endophytic fungi isolated from wheat (Triticum durum), J. Plant. Prot. Res. 53 (2013) 128-36.

[13]. H. Muzzamal, R. Sarwar, I. Sajid, S. Hasnain, Isolation, identification and screening of endophytic bacteria antagonistic to biofilm formers, Pak. J. Zool. 44 (2012) 249-57.

[14]. S.J. Bhore, N. Ravichantar, C.Y. Loh, N. Ravichantar, C.Y. Loh, Screening of endophytic bacteria isolated from leaves of Sambung Nyawa [Gynura procumbens (Lour.) Merr.] for cytokininlike compounds, Bioinformation. 5 (2010) 191-7.

[15]. K. Ramasamy, S.M. Lim, H.A. Bakar, N. Ismail, M.S. Ismail, M.F. Ali, Antimicrobial and cytotoxic activities of Malaysian endophytes, Phytother. Res. 24 (2010) 640-3.

[16]. R.M. Prabhavathi, M.P. Prasad, M. Jayaramu, Studies on qualitative and quantitative phytochemical analysis of Cissus quadrangularis, Adv. Appl. Sci. Res. 7 (2016) 11-7.

[17]. R. Suthakaran, G. Somasekhar, C. Sridevi, M. Marikannan, K. Suganthi, G. Nagarajan, Synthesis, antiinflammatory, antioxidant and antibacterial activities of 7-methoxy benzofuran pyrazoline derivatives, Asian J. Chem. 19 (2007) 3353-62.

[18]. C. Sridevi, M. Selvaraj, V. Mani, K.K. Selvarajan, J.I. Mohammad, B. Kaveti, Identification of novel acetylcholinesterase inhibitors: Indolopyrazoline derivatives and molecular docking studies, Bioorganic Chem. 67 (2016) 9-17.

[19]. C. Sridevi, S.A. Shaikh, J.I. Mohammad, K.K. Selvarajan, A.R. Nemala, C.H. Khaw, C.F. Teoh, T.H. Kee, In vitro antioxidant and in vivo antidepressant activity of green synthesized 
azomethine derivatives of cinnamaldehyde, Indian J. Pharmacol. 49 (2017) 229.

[20]. C. Sridevi, M. Selvaraj, V. Mani, J.I. Mohammad, K.K. Selvarajan, S.S. Akhtar, M. Marikannan, S. Raj, L.K. Teh, M.Z. Salleh, Synthesis of azomethines derived from cinnamaldehyde and vanillin: in vitro aetylcholinesterase inhibitory, antioxidant and in silico molecular docking studies, Med. Chem. Res. 27 (2018) 807-16.

[21]. T. Noreen, M. Taha, S. Imran, C. Sridevi, F. Rahim, M. Selvaraj, Synthesis of alpha amylase inhibitors based on privileged indole scaffold, Bioorganic Chem. 72 (2017) 248-55.

[22]. X. Yuan, X. Hu, Y. Liu, H. Sun, Z. Zhang, D. Cheng, In vitro and in vivo anti-diabetic activity of extracts from Actinidia kolomikta, Int. J. Biol. 6 (2014) 1-10.

[23]. L. Sun, H. Zhang, Y. Zhuang, Preparation of free, soluble conjugate, and insoluble-bound phenolic compounds from peels of rambutan (Nephelium lappaceum) and evaluation of antioxidant activities in vitro, J. Food Sci. 77 (2012) C198C204.

[24]. P. Chao, C. Hsu, M. Yin, Anti-inflammatory and anti-coagulatory activities of caffeic acid and ellagic acid in cardiac tissue of diabetic mice, Nutr. Metab. 6 (2009) 79-82.

[25]. G. Strobel, B. Daisy, U. Castillo, J. Harper, Natural products from endophytic microorganisms, J. Nat. Prod. 67 (2004) 257-68.

[26]. J.T. Coombs, C.M.M. Franco, Isolation and identification of actinobacteria from surfacesterilized wheat roots, Appl. Environ. Microbiol. 69 (2003) 5603-8.

[27]. C.O. Godstime, O.E. Felix, O.J. Augustina, O.E. Christopher, Mechanisms of antimicrobial actions of phytochemicals against enteric pathogens-a review, J. Pharm. Chem. Biol. Sci. 2 (2014) 77-85.
[28]. M. Jayasri, M. Lazar, A. Radha, A report on the antioxidant activity of leaves and rhizomes of Costus pictus D. Don, Int. J. Integr. Biol. 5 (2009) 20-26.

[29]. C. Sridevi, J.I. Mohammad, S. Vijayabalan, N.D. Vaipuri, K.K. Selvarajan, A.R. Nemala, Quantitative estimation and antimicrobial potential of ethanol extract of Durio zibethinus Murr. Leaves, Asian J. Pharm. Clin. Res.10 (2017) 2514.

[30]. C. Sridevi, E.W. Yiik, J.I. Mohammad, S. Vijayabalan, Screening antimicrobial potential for Malaysian originated Tamarindus indica ethanolic leaves extract, Asian J. Pharm. Clin. Res. 11 (2018) 361-63.

[31]. A.K. Esmaeili, R.M. Taha, S. Mohajer, B. Banisalam, Antioxidant activity and total phenolic and flavonoid content of various solvent extracts from in vivo and in vitro grown Trifolium pratense L. (red clover), BioMed Res. Int. 2015 (2015) 643285.

[32]. C.A. Tarling, K. Woods, R. Zhang, H.C. Brastianos, G.D. Brayer, R.J. Andersen, The search for novel human pancreatic $\alpha$-amylase inhibitors: High-throughput screening of terrestrial and marine natural product extracts, ChemBioChem 9 (2008) 433-8.

[33]. E. Apostolidis, Y.I. Kwon, K. Shetty, Inhibitory potential of herb, fruit, and fungal-enriched cheese against key enzymes linked to type 2 diabetes and hypertension, Innov. Food. Sci. Emerg. Technol. 8 (2007) 46-54.

[34]. W. David, Rithcie: Evaluation of protein docking predictions using Hex 3.1 in CAPRI rounds 1 and 2, Proteins 52 (2003) 98-106.

Received: 02.12 .2018

Received in revised form: 30.09.2019

Accepted: 10.10.2019 